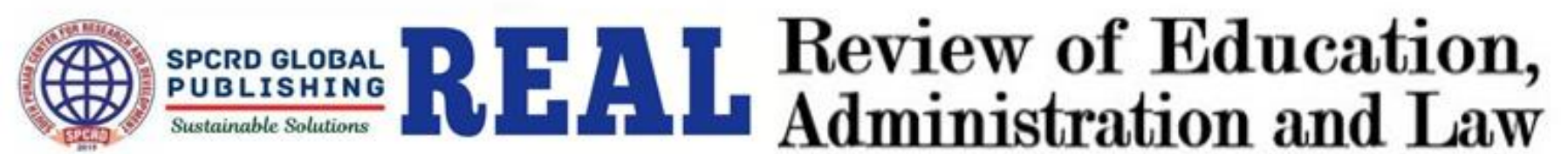 \\ Journal homepage: http://real.spcrd.org ISSN (Print): 2708-1788 ISSN (Online): 2708-3667
}

\section{Institutional Role on Personality Grooming of Students at Higher Secondary Level}

\author{
${ }^{a}$ Sonia Rafique, ${ }^{b}$ Ijaz Ahmad Tatlah, ${ }^{c}$ Muhammad Shabbir \\ ${ }^{a}$ Punjab Group of Colleges, Pattoki, Pakistan \\ Email: imransonia17@yahoo.com \\ ${ }^{\mathrm{b}}$ Assistant Professor, University of Education, Lahore, Pakistan \\ Email: tatlah@ue.edu.pk \\ ${ }^{c}$ Assistant Professor, Department of Education, Govt. College University, Faisalabad Punjab, Pakistan \\ Email: mskhalid6o6@yahoo.com
}

\begin{tabular}{|c|c|}
\hline ARTICLE DETAILS & ABSTRACT \\
\hline History: & \multirow{9}{*}{$\begin{array}{l}\text { The institute defines its aims and sets educational objectives adapted to } \\
\text { these aims. The institute has a clear and distinct sense of its core values } \\
\text { and character, of its distinctive elements, of its place both in colleges and } \\
\text { in society, and of its contribution to the public good. The aims of the } \\
\text { study were (i). To explore the practices for development of personality in } \\
\text { institutions. (ii) To identify the role of administrators of institutes for } \\
\text { students 'personality development. (iii)To determine which sector is } \\
\text { more competent in doing better personality development at higher } \\
\text { secondary level in private and public sector institutes. With survey } \\
\text { design the study was descriptive in its nature. The population of the } \\
\text { study was all private and public colleges of Punjab Province. Six } \\
\text { hundred and twenty-eight out of seven hundred and twenty students, } \\
\text { and also thirty administrators out of thirty-two, participated in the } \\
\text { research. Instrument was tested by conducting Pilot testing with } \\
\text { ( } \alpha=87 \text { ) reliability. Parametric statistics and summary statistics were } \\
\text { menu plated to check the assumption, Normality tests and Boxplot were } \\
\text { applied. To compare the private and public institutes, Non-parametric } \\
\text { test was applied on the given information. It was concluded from the } \\
\text { study that (i) Activities related to personality development, are doing in } \\
\text { institutions. (ii) Administrators are doing their job in personality } \\
\text { development among boys and girls at higher secondary level. (iii) } \\
\text { Private sector is doing better job to the development of student's } \\
\text { personality than public sector. }\end{array}$} \\
\hline d 29 July 2020 & \\
\hline Available Online 30 Sep 2020 & \\
\hline Keywords: & \\
\hline & \\
\hline Personality Grooming & \\
\hline JEL Clas & \\
\hline Do2, & \\
\hline DOI: 10.47067/real.v3i2.53 & \\
\hline
\end{tabular}

(C) 2020 The authors. Published by SPCRD Global Publishing. This is an open access article under the Creative Commons AttributionNonCommercial 4.0

Corresponding author's email address: imransonia17@yahoo.com 


\section{Introduction}

If the reality orientation is positive and strong there is every chance of happiness. A healthy attitude is the outcome of positive perception of reality and relationship. A balanced healthy educational program is needed most in education today (Robbins, 2001).

Personality plays a key role in deciding to start a professional life. An attractive man, a positive attitude or a smile is not counted as personality, but describing the entire system in one person's mental growth and psychological development (Kinicki and Kreitner, 2003).

Yasoda (2013) points out that development is a constant progression, from pregnancy to death. Even if corporeal changes may be more pronounced, we also have social, personal, cognitive, intellectual and educational changes. Traditionally, the theme of human development is more in the interest of educational psychologists.

\section{Statement of the Problem}

Personality development of students' is educational goal and society's major concern. Due to the facilities provided by all sectors, all sections are supported to play a role in this regard. The present research aims to show the institutional impacts, to personalized intermediate level students at the Colleges of Public and Private sectors.

\section{Objectives of the study}

- To explore the practices for development of personality in institutions.

- To identify the role of administrators of institutes for students 'personality development.

- To determine which sector is more competent in doing better personality development at higher secondary level in private and public sector institutes.

\section{Review of Related Literature}

Education supports melodious development of the individual. It upsurges the cognitive, social and moral modification of the individual in the society. It delivers individuals greater choices and opportunities to develop their lives. Education is measured the best significant approach of humanoid capital development, which is requirement for supporting the improvement of nations (Ormrod, 2016).

Yasoda \& Nirmalajyothi (2013) argued that personality depends mainly on how one perceives himself and his environment. Self-knowledge has been rightly emphasized upon one's relationship with the world around him. The relationship is congenial and conducive if one's perception about him is happy and healthy. Education helps to form perception in oneself in relation to reality.

Bhatia (2011) suggested that personality is all that psychologically speaking an individual is. It is as well the one's behavior totality towards others and oneself. It contains the whole thing about an individual, his emotional, mental, physical, spiritual and social temperaments. It is all that a person has about him.

Snowman, McCown \& Biehier. (2012) stated that personality exact definition is yet to be arrived at, but intelligence is a term which is commonly used for it. Personality is a globally perceptional by society, such characteristics are marked by whom an individual can be illustrious from others is called personality. Generally, we take notice of such persons who are able to attract our attention as somewhat different from others. Hypocrites first divided all human beings into four characteristic groups according to their temperament as follows:-(a) Choleric or those who are easily excitable, 
(b)Emotionally feeble and pessimistic or Sad (c)Emotionally insensitive or Calm(d)Determined and optimistic or confident. Different genre of students are living hostels who impel and influence their fellows personality too (Sajid \& Tatlah, 2020).

Kundu \& Tutoo (2011) quoted the concepts of Hypocrites that personality differences were caused by certain liver secretions, they affect our emotional life. Centuries after Hypocrites, William James in 1911 divided all human beings into two groups: One prone to accept the established ideals that he called rationalist and the other ready to test and verify things that he called empiricist.

Kumar (2004) stated that All port tried to find personality traits under five broad divisions namely: Intelligence, Motility, Temperature, Self-expression and Sociability. Each of these traits was subdivided into a number of factors. All port's characteristics are twenty four as follows:-

Intelligence:

(a) Capacity to remove obstacles

(b) Memory which is associated with learning

(c)Capacity to see interrelationships

(d)Creative imagination

(e)Capacity to adjust to new situations

Motility:
(a)Capacity for work
(b) Methods of working
(c) Perseverance
(d)General Ability

Temperament:
(a) Emotional strength
(b) Breadth or narrowness in the emotional field
(c) Capacity to control one's emotions
(d) Tendencies
(e)Treatment towards other persons

Self-Expression:
(a) Capacity to start work
(b)Insight
(c) Compensatory capacity and capacity to bear loss
(d) Extraversion or introversion
(e)Aggressive or submissive attitude

Sociability:
(a) Social adjustment
(b) Capacity to share in social activities
(c) Self-centered or Self-evasive attitude
(d)Character

Rashid (2005) defines development of personality as the stability, consistency as well as continuity of individuals over time and how persons transformation over time. The stability and change 
of each of these facts requires definition and rehabilitation. Personal stability and change have many forms.

Batatcharia (2006) points out that there have different opinions of different psychologists about the personality meaning. Most people believe that the Latin's word "Persona" is the base of word "personality", which speaks of to the melodramatic mask destroyed by actors of Roman in the dramas of Greek.

In her Ph.D. thesis Perveen Azra (2007) quoted reasons of personality can be determined by quality or feature, which is a very distinctive feature of an individual and is a significant part of other's general impression.

Michelle, Shoda and Smith (2004) have pointed out that there are many definitions of "personality", but the universal sense not accepts one and only meaning. In common use, it often comes with social skills and performance. In this use, the personality is capable of generating positive feedback from others in their specific contacts.

\subsection{Factors that Shape Personality Development}

Rashid (2005) noted that personality formation involves many potential factors. These are usually considered genetic and environmental. Conversely, it seems that the values acquisition, expectations and beliefs are more focused on socialization and exceptional understandings, particularly in infantile.

According to Woolffolk (2008) personal development is the evolution of organizational behavior patterns and attitudes that make people unique. This happens through constant communication of malaise, personality and surroundings. Nayak \& Rabert (2010) specified that all ordinary people always want to become better. There are ways to achieve this change in personality. If anyone can comprehend these rudimentary instructions, he can bring him what he wants. This is the first step of the plan. Create a detailed plan for what you want to do and how to achieve it. The plan must be focused, clear, and applied. In the meanwhile, impression should be strong and positive for best personality development and group competitions improve it in long term maintenance of one's personality.

Sadler,M (2004) described that a person's appearance can be his personality development. Conversely, the normal working of the nerves and glands is imperative in the growth of the full personality. Only by designing willpower and determination, an average individual become an enormous person. Siddiqui (2017) stated that the pureness of thought is one of the factors that upturn the will and strength of mind. If we need to increase will power, we must stay away from mistrustfulness, untruthful accusations and small negotiations.

\subsection{Effect of the environment on the development of personality}

Differences of genetic in mood are just the tendency to conduct you in a specific means, experience and environmental conditions which has shown that different children have the same tendency in diverse ways. There are two important environmental factors in which personality development influences, are cultural expectations and family dynamics (Rashid, 2005).

Numerous parentages and other caring relatives (older siblings, grandparents) love with the newborn baby, the baby constantly provides services for physical and mental needs. Children's have no close contact with their parents or other people may be unformed, helpless, hated, and after exposure to 
malicious and aggressive behavior (Mangle, 2002).

\subsection{Three Major Fields of Personality Development.}

There are three major fields which influence an individual personality. These are Cognitive, Social and Moral development of personality.

Development of cognition is focused on the development of children in psychology and neurology, where processing of information, conceptualization, conceptual competence, language learning and other aspects of brain development are focused (Sadler, 2004).

According to Siddiqui (2017) the terms of cognition thinking, processing of memory and the process of cognitive development, these actions mean long-term changes in a personality. It belongs to several geographically divergent concepts, and according to several theories one is the guide of all theorist, it is the most qualified, well-known and progressive theorist Jean Piaget which describe many theoretical stages of cognitive development.

\subsection{Social Development of Personality}

Howe (2009) interacted that human beings have an essential social existence. In life of modern era, people need more and more traditional relationships than ever. In fact, not a single person can afford to be completely or partially separated or isolated life style.

Adult and growing children are not only developed in the body's spiritual and emotive behavior, but also in development of social context. (MidgleyJames, 2013). The range of social activities of the children is associated with their development, namely, physical, psychological and emotional properties. (Atkinson \& voudi, 2000).

Brown \& Lichter (2006) stated that a child grows, not only in the development of physical, psychological, emotional and behavior but also in his societal comportment. It is a recognized communal attitude that makes himself a satisfactory social human.

\subsection{Moral Development of Personality}

According to Chartier, (2003) in society, morality is expressed as a series of rules imposed on individuals. Threats and punishments that may be subtle and extreme may be developed from various sources such as family, culture, and society

Timm (2000) considers morality to be a behavioral norm expressed by individuals within the individuals and in between the group. People have good or bad opinion. They prefer others to do with them what they want to do with others.

Khanam (2008) points out that ethical issue include basic issues such as integrity, equality, impartiality, fundamental human rights, like right wrong good and bad etc. Because norms and cultural values have a strong influence on individual thinking and behavior, ethical problems are although regulated by social and cultural factors, problems such as liars, robbers, murders, judicial values are often regarded as different cultures (Nucci, 2001, p. 6).

Morality is the basis of human psychology and a person's ethical beliefs. It is a broad aspect, psychology is influenced by academic, cognitive and emotional mechanisms (Roberts, B.W., Wood, D., \& Caspi, A. 2010). 
Krause, Bochner \& Duchesne, (2003) describe that value is an additional perception of moral development. Values are personal goals for valuable things, good things, and bad things.

Ethics are narrowly related to their social and cultural backgrounds. They are not one part of the process of socialization, as well as interactions between individuals and communities; they cannot develop in isolation (Kluckhohn (2004).

Teachers say that in defining a good personality, it should include developing moral responsibility and ethical moral conduct. Discipline, ethical values, goals, free social processes, ideas, positive thinking ability and character are the standards of a person (Huitt, 2004, p. 4).

\section{Research Methodology}

Survey design was used in this descriptive study. Quantitative approach used by the researcher to conducting the study. For attaining valuable information, quantitative approach is best, if the scholar wants to apply the study's results on to the target population (Creswell, 2005).

\subsection{Population}

\subsubsection{Target population}

Students and administrators of private and public sector colleges in Punjab Province were the population of the study.

\subsubsection{Accessible population}

One Public male College and one Public female College was selected randomly from each division of Punjab Province. There are total nine divisions in Punjab Province. Eighteen Private colleges (One Private male College and one Private female College was selected randomly from each division) were selected from Punjab Group of Colleges. Total 36 public and private colleges were selected from nine divisional headquarters of Punjab Province.

\subsection{Sample of the study}

Randomly selected eighteen public sector colleges and eighteen private sector colleges from nine divisions of Punjab Province are the sample of the study. From each college, twenty students and an administrator were selected as sample. Students were selected randomly. Out of seven hundred and twenty students, six hundred and twenty-eight students responded in the research and thirty-two administrators out of thirty-six participated in the research.

Table: 1.1 Comparison between the Public and Private Sector Colleges Regarding Cognitive, Social and Moral Development on the Perception of students 


\begin{tabular}{|l|l|l|l|l|l|l|}
\hline Scales & \multicolumn{2}{l|l}{ Public } & \multicolumn{2}{l|}{ Private } & \multicolumn{2}{l|}{ Mann-Whitney U } \\
\hline & $M$ & $S D$ & $M$ & $S D$ & Z & P \\
\hline Cognitive Development & 2.69 & .30 & 4.3 & .36 & -21 & $<.001$ \\
\hline Social Development & & & & & & \\
\hline Moral Development & 3.88 & .29 & 4.14 & .48 & -8.3 & $<.001$ \\
\hline & 3.94 & .50 & 4.00 & .60 & -2.2 & .025 \\
\hline
\end{tabular}

Table 1.1 reflects that to compare students of Private and Public Sector colleges on moral, cognitive and social development in students at higher secondary level, Mann-Whitney U test was conducted. The results of Mann-Whitney $U$ test indicate that there is statistically significant difference $(\mathrm{p}<.05)$ between students of public and private sector colleges concerning moral, cognitive, social a development among students. The social development among students of public sector $(\mathrm{M}=3.88$, $\mathrm{SD}=.29)$ is less than private sector $(\mathrm{M}=4.14, \mathrm{SD}=.48)$. The cognitive development in students of public sector $(\mathrm{M}=2.69, \mathrm{SD}=.30)$ is less than private sector $(\mathrm{M}=4.3, \mathrm{SD}=.36)$. The moral development among students of public sector $(\mathrm{M}=3.94, \mathrm{SD}=.50)$ is less than private sector $(\mathrm{M}=4.00, \mathrm{SD}=.60)$. Table also shows that cognitive, moral and social development in students at higher secondary level of public is low than private sector colleges.

Table: 1.2 Comparisons between the Perception of Administrators of Private and Public Sector Colleges Regarding Cognitive, Social and Moral Development

\begin{tabular}{|l|l|l|l|l|l|l|}
\hline Scales & \multicolumn{3}{l}{ Public } & \multicolumn{2}{l|}{ Private } & \multicolumn{2}{l|}{ Mann-Whitney U } \\
\hline & $\boldsymbol{M}$ & $\boldsymbol{S D}$ & $\boldsymbol{M}$ & $\boldsymbol{S D}$ & $\mathrm{Z}$ & P \\
\hline Cognitive Development & 3.77 & .31 & 4.51 & .22 & -4.5 & .000 \\
\hline Social Development & 3.87 & .35 & 4.31 & .34 & -3.2 & .000 \\
\hline Moral Development & 3.94 & .45 & 4.21 & .57 & -2.0 & .533 \\
\hline
\end{tabular}

Table 1.2 reflects that Mann-Whitney $U$ test was conducted to compare the perception of administrators of public and private sector colleges regarding cognitive, social and moral development in students of higher secondary level. The results of Mann-Whitney $U$ test indicate that there is statistically significant difference $(\mathrm{p}<.05)$ between students of Public and Private Sector colleges regarding cognitive, social and moral development in students of intermediate level. according to the perception of administrators the social development among students of public sector $(\mathrm{M}=3.87, \mathrm{SD}=.35)$ is less than private sector $(\mathrm{M}=4.31, \mathrm{SD}=.34)$.Cognitive development in students of public sector $(\mathrm{M}=3.77, \mathrm{SD}=.31)$ is less than private sector $(\mathrm{M}=4.51, \mathrm{SD}=.22)$. The moral development among students of public sector $(\mathrm{M}=3.94, \mathrm{SD}=.45)$ is less than private sector $(\mathrm{M}=4.21, \mathrm{SD}=.57)$. Table shows that moral, cognitive and social development in students of higher secondary level of public sector colleges is less than the students of private sector colleges. 


\section{Discussion}

Present study aimed at examining status of personality development of higher secondary level students. The findings of the current study support the literature reviewed. Results of several studies show that the college years are fertile ground for the quick growth of cogitation among students (Maqbool,2011). Woolffolk Anita (2008) also noted that private colleges are the places of intellectual and ethical development.

Roberts, B.W., Wood, D., \& Caspi, A. (2010) have major research on this topic and illustrates that "Because our values, character and personality directly affect relationships with others, the moral spiritual side will have a big influence on our personal interaction. Second, this definition of morality is believed to have many aspects of ethical behavior, including dynamic interactions during thought, behaviors during actions and emotion with each other's.

Faculty members who comprehend these changes may develop such courses and activities that light students' needs and support their gradual growth (Bhatia, 2005).

Gretchen (2017) an American psychologist, fostering the society of the origins of moral education, explains that much of the moral behavior driven by development in individuals creates a sense of community and stability.

Results of present study also show that colleges are the places where personality development occurs. Results show that cognitive, social and moral development in students of higher secondary level of private sector is improved than public sector colleges.

\section{Recommendations}

Following recommendations are presented in the light of above discussion and conclusion:

- Public Sector colleges may pay more attention to the moral and social development along with cognitive development.

- Co-curricular activities are much helpful in building social and moral aspects of students so they should be the regular feature the colleges.

- Similar researches should be conducted in Public and private Schools of Punjab respectively.

\section{References}

Ahmad Maqbool(2011). Development and Cognition;Ilmi Kitab Khana,Urdu Bazar Lahore.

Atkinson.R \& VoudiDa,S,(2000).The Concept of Social Exclusion in the European Union: Context and Development Possibilities, Journal of Common Market.

Bhatia.(2011). Psychology of Teaching-Learning Process. Ansari Road, DaryaganjNew Dehli.

Bhattacharya (2006).Psychological Foundation of Education. Atlantic: B-2, Vishal Enclave, Opp. Rajouri Garden, New Delhi.

Brown, J.B. \&Lichter, D.T. (2006) Child Disadvantage, Adolescent Development and Pro-Social Behavior in Early Adulthood. Ohio: National Science Foundation, Initiative in Population Research, Ohio State University.

Chartier, M.J., Walker, J.R., \& Stein, M.B. (2003).Considering comorbidity in social phobia. Social Psychiatry and Psychiatric Epidemiology, 38, 728-734.

Gretchen ,(2017)."Leading from within Conscious Social Change and Mindfulness for Social Innovation”, Cambridge ,Massachusetts London, England The MIT Press. 
Howe David,(2009).”A Brief Introduction to Social Work Theory”Macmillan International Higher Eucation.

Huitt, W. (2004).Moral and character development.Educational Psychology Interactive.Valdosta, GA: Valdosta State University. Retrieved 20016, fromhttp://chiron.valdosta.edu/whuitt/col/morchr/morchr.htmlhttp://en.m.wikipedia.org>wiki>Rob ert

KhanamAfifa (2008),"Effect of Religious Education on The Moral Development of Children” Ph.D unpublished thesisto Institute of Education and Research University of the Punjab Lahore.

Kinicki,A.,\&Kreitner,R.(2003).Organizational behavior: Keyconcepts, skills\&bestpractices: McGraw-Hill. Kluckhohn (2004).Values and Value Orientation in the theory of Action.FreePress ,New York.

Krause, K-L., Bochner, S., \& Duchesne, S. (2003). Educational psychology for learning and teaching. Southbank, VIC: Nelson, Australia .

Kumar.(2004). Modern Teaching of Education Psychology.J.L. Kumar for AnmolPublications Pvt. Ltd, New Delhi - 110002 and Printed at Mehra Offset Press, Delhi.

Kundu\&Tutoo.(2011). Educational Psychology. Sterling Publishers Private Limited: 4-59, Okla Industrial Area, Phase-II, New Delhi.

Mangle,S.K.,Statistics in Psychology and Education, New Delhi, Prentic Hall of India(2ndrevised ediotion),2002.

MidgleyJames (2013).social development theory and Practice.Sage publications.

Nucci, L. P. (2001). Education in the moral domain. Cambridge, England: Cambridge University Press.

OrmrodEliss (2016). Educational Psychology. Pearson India Education Services Pvt.Ltd,

PerveenAzra (2007),"Effect of Home Environment on Personality and Academic achievement of Students of Grade 12 In Rawalpindi Division” Ph.D unpublished thesis to National University of Modern Languages, Islamabad.

Rashid.(2005). Study Guide on Education Psychology.AllamaIqbal Open University, H-8, Islamabad.

Robbins, S. P. (2001). Organizational behavior(9th ed.). New Jersey: Prentice-Hall. Sadker,M.,"Gender equity in the classroom”,INM.Kimmel(Ed.),The Gender society redear, 2ndedition.York:Oxford University Press, 2004.

Roberts, B. W., Wood, D., \& Caspi, A. (2010). The development of personality traits in adulthood. In O. P. John, R. W. Robins, \& L. A. Pervi (Eds.), Handbook of personality: Theory and research (3rd ed., pp. 375-398). New York, NY: Guilford Press.

Sadler.M,(2004.)"Gender equity in the classroom”,INM.Kimmel(Ed.),The Gender society redear, 2nd edition.York:Oxford University Press.

Sajid, M. A., Tatlah, I. A., \& Butt, I. H. (2020). Causes of Drug Abuse Among University Students in Pakistan: Variation by Gender And Drug Type.

Siddiqui.(2017). Educational Psychology. A P H Publishing Corporation: 4435-36/7, Ansari road, Darya Ganj New Delhi-110002.

Skinner. (2009). Education Psychology: Fourth Edition. AsokeK.Ghosh, PHI Learning Private Limited, M-97, Connaught Circus, New Delhi.

sMischel Walter, Shoda Yuichi, \& Smith E. Ronald (2004).Introduction to Personality (pp. 47-6o).John Wiley \& Sons, INC.

Snowman, McCown\&Biehier. (2012). Psychology Applied to Teaching. Printed in Canada.

Timm, D. (2000). Defining Ethics and Morality.American Sign Language InterpretingResources, 24 September 2000.<file://D:/moral \%20 development/Defining\%2oEthics\%20\%26\%20Morality\%2oby\%2oDamon\%2oTimm.htm>.28 Jan 2017.

Woolffolk Anita. (2008). Educational Psychology.Person Education, Inc. and Dorling Kindersley Publishing Inc. 
Yasoda.R\&Nirmalajyothi.M (2013).Education and Human values. A P H Publishing Corporation: 4435-36/7, Ansari road, Darya Ganj New Delhi-110002. 